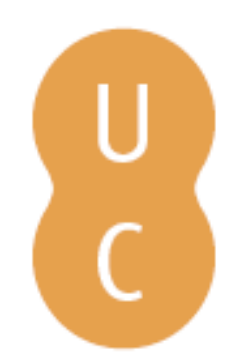

\title{
nommalina
}

\section{"Desconstruindo a restituição de peças africanas: ecos da iniciativa do Museu do Dundo (1951-75) nas propostas actuais de Emmanuel Macron e Sindika Dokolo": uma visão desde a História}

\author{
Autor(es): Baltazar, Isabel
}

Publicado por: Imprensa da Universidade de Coimbra

URL persistente:

URI:http://hdl.handle.net/10316.2/47306

DOI:

DOI:https://doi.org/10.14195/978-989-26-1849-4_15

Accessed : $\quad$ 26-Apr-2023 11:46:09

A navegação consulta e descarregamento dos títulos inseridos nas Bibliotecas Digitais UC Digitalis, UC Pombalina e UC Impactum, pressupõem a aceitação plena e sem reservas dos Termos e Condições de Uso destas Bibliotecas Digitais, disponíveis em https://digitalis.uc.pt/pt-pt/termos.

Conforme exposto nos referidos Termos e Condições de Uso, o descarregamento de títulos de acesso restrito requer uma licença válida de autorização devendo o utilizador aceder ao(s) documento(s) a partir de um endereço de IP da instituição detentora da supramencionada licença.

Ao utilizador é apenas permitido o descarregamento para uso pessoal, pelo que o emprego do(s) título(s) descarregado(s) para outro fim, designadamente comercial, carece de autorização do respetivo autor ou editor da obra.

Na medida em que todas as obras da UC Digitalis se encontram protegidas pelo Código do Direito de Autor e Direitos Conexos e demais legislação aplicável, toda a cópia, parcial ou total, deste documento, nos casos em que é legalmente admitida, deverá conter ou fazer-se acompanhar por este aviso.

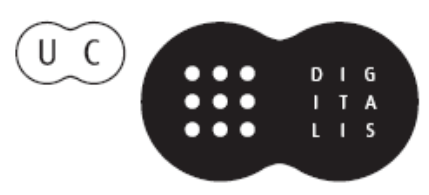


Euro-Atlântico:

Espaço de Diálogos

Isabel Maria Freitas Valente

Iranilson Buriti de Oliveira

(Coord)

\section{VISÕES \\ INTERDISCIPLINARES \\ DA EUROPA \\ E DO MUNDO:}

uma experiência de convergência

disciplinar em homenagem a

Maria Manuela Tavares Ribeiro

Alexandra Aragão

Isabel Maria Freitas Valente

Dulce Lopes

(org.)

Editora da Universidade Federal de Campina Grande

Imprensa da Universidade de Coimbra

2019 


\section{"DESCONSTRUINDO A RESTITUIÇÃO DE PEÇAS AFRICANAS: ECOS DA INICIATIVA DO MUSEU DO DUNDO (1951-75) NAS PROPOSTAS ACTUAIS DE EMMANUEL MACRON E SINDIKA DOKOLO”, UMA VISÃO DESDE A HISTÓRIA}

João Figueiredo começa com uma notícia do Jornal Público de que "Duas máscaras de raparigas [mwana pwo], uma taça, um tamborete, um cachimbo e uma cadeira são as seis peças que a Fundação Sindika Dokolo devolveu esta quinta-feira [8 de junho de 2018] ao Museu do Dundo, instituição no nordeste de Angola que é o repositório do riquíssimo património cultural do povo Chokwe"1. Aparentemente esta notícia nada teria de extraordinário, não fosse o seu simbolismo cultural da devolução de seis peças de arte clássica africana ao Museu do Dundo. Contudo, como salienta o autor, esta notícia do Público e o facto de Macron ter aproveitado a visita de Estado de João Lourenço ${ }^{2}$, Presidente da Republica angolano, para voltar a referir o seu desígnio de concretizar "restituições temporárias ou definitivas do património africano"3, mostra como a cultura está ao serviço da política.

$\mathrm{O}$ mais interessante deste artigo é ficar provado de que a cultura pode ser mediatizada pela política e, se podia passar despercebida pelo grande público, passa a ser notícia se o protagonismo político a instrumentalizar. Assim se explica a atenção mediática dedicada ao tema neste caso tendo como protagonistas Macron e Dokolo, o que permite desde logo perceber que os discursos políticos se servem de políticas culturais para passarem mensagens políticas. E, paradoxalmente, e

1 "Sindika Dokolo devolve a Angola novas peças da cultura Chokwe", in Público, 8 de junho de 2018. Disponível em: https://www.publico.pt/2018/06/08/culturaipsilon/noticia/sindika-dokolo-devolve-a-angola-novas-pecas-da-cultura-chokwe-1833737 (consultado a 10 de junho de 2018).

2 A 28 de maio de 2018.

3 "Angola na hora francesa... 
apesar do empresário afrodescendente ter um discurso fortemente contestatário das políticas culturais públicas europeias, não existem clivagens de fundo entre a sua posição e a do Presidente da República francês, como mostra o autor.

É curioso como João Figueiredo, denuncia as posições de Macron e Dokolo tão próximas entre outras, como a de Isabel dos Santos que também defende a devolução ao continente africano de obras dos antepassados, da cultura, da história, a arte roubada, presente em museus na Europa. A política transformou em moda 'África' e o seu 'património' e a relação dos povos africanos com a sua história. O mais sintomático de tudo isto é o facto da existência de discursos e politicas europeias que vêm dar relevância a obras de arte antes esquecidas, e que renascem ao sabor de discursos politicamente correctos de recuperação de uma genuína arte africana que antes se tinha europeizado.

O autor mostra como as peças de museus de uma arte clássica africana absorvida por museus europeus podem ser devolvidas às origens por mera conveniência política e que a arte é um instrumento de grande habilidade diplomática.Em Macron, dos Santos e Dokolo, 'África' surge como um lugar de recuperação as colecções privadas e das peças existentes nos museus europeus, desconstruindo a ideia de África há vários séculos entendida no Ocidente como um local de 'inversão' ou 'falta' de valores, repondo a verdade de que também na Europa e no 'Ocidente' se vive ausência de valores, e que as identidades são por si mesmas, ambas com o mesmo valor. Fica a ideia de que não existe um atraso africano e um desenvolvimento europeu, porque as culturas não se medem em padrões económicos. Por outras palavras, cada cultura é única e valorativa por si mesma e que se devem preservar as tradições e deixar que fiquem nos seus lugares. Daí a restituição de peças agora em moda política que, por acaso, vem ao encontro da preservação e patrimónios comuns e das tradições genuínas das suas culturas.

Neste sentido, não há bons museus europeus nem os africanos, mas sim uma identidade própria de cada um que se deve a todo o custo preservar. Os museus em estilo europeu só são "bons museus" na Europa e os africanos não se devem europeizar, sob pena de se 
perderem preciosas identidades.

Ficou a grande questão enunciada por João Figueiredo: "Não devem, portanto, as peças africanas ser devolvidas aos seus contextos de origem? Sim, em certos casos, mas apenas quando esta acção for passível de ser enquadrada sem violência adicional nos "imaginários" locais, a partir de uma conceptualização autóctone, dentro do possível, descolonizada e actual." Mas nunca numa repatriação instrumentalizada enquanto forma de divulgar valores ou 'cânones' de cunho 'Ocidental', quer estes sejam relacionados com a 'Arte', o 'Património' ou o 'Desenvolvimento'.

Ficam questões para pensarmos: "O que fazer então com esta 'herança' duplamente indesejada? Em Portugal, a constituição de um Museu do Colonialismo seria uma boa resposta, como refere o autor, um projecto para o qual seria necessário mobilizar toda a nossa capacidade interdisciplinar. E não repatriar todo o património, negando aos afrodescendentes residentes em Portugal o direito a um Museu capaz de testemunhar as tribulações a que a expansão colonial e imperial portuguesa sujeitou os seus e nossos antepassados. Fica a solução de equilíbrio cultural e não da cultura instrumentalizada por políticas. 